\title{
ЗМІНА СТАНУ КОМПЛЕКСУ ЛЕГЕНЕВОГО СУРФАКТАНТУ ПРИ ВТРУЧАННЯХ $З$ ПРИВОДУ ГОСТРОГО АОРТАЛЬНОГО СИНДРОМУ В УМОВАХ ШТУЧНОГО КРОВООБІГУ
}

\author{
Канд. мед. наук Бучнєва О. В. \\ Україна, Харків, ДУ «Інститут загальної та невідкладної хірургї̈ ім. В. Т. Зайцева \\ НАМН України»
}

DOI: https://doi.org/10.31435/rsglobal_ws/31052019/6515

\section{ARTICLE INFO}

Received: 07 March 2019

Accepted: 13 May 2019

Published: 31 May 2019

\section{KEYWORDS}

aorta, bronchial alveolar lavage, cytological examination, surfactant, acute aortic syndrome.

\begin{abstract}
Objective. To study changes in the state of pulmonary surfactant complex during interventions in acute aortic syndrome.

Materials and methods. Biochemical analysis and cytological study were conducted on 142 samples obtained during the bronchoalveolar lavage performed intraoperatively or in the early postoperative period.

Results. It was determined that in the postoperative period the bronchoalveolar fluid of patients with disorders of gas exchange contained significantly more general protein, albumin and fibrinogen, indicating an increase in the alveolar membrane transport. The higher content of plasma proteins in the alveolar fluid of patients with ARDS was due to low phospholipid content, reflecting damage to the lung surfactant system.

Conclusion. The obtained data indicates the damage of pulmonary surfactant complex followed by an increase in the alveolar membrane transport leading to development of acute respiratory distress syndrome after surgery on the aorta.
\end{abstract}

Citation: Бучнєва O. В. (2019) Zmina Stanu Kompleksu Lehenevoho Surfaktantu pry Vtruchanniakh z Pryvodu Hostroho Aortalnoho Syndromu v Umovakh Shtuchnoho Krovoobihu. World Science. 5(45), Vol.2. doi: 10.31435/rsglobal_ws/31052019/6515

Copyright: (C) 2019 Бучнєва О. В. This is an open-access article distributed under the terms of the Creative Commons Attribution License (CC BY). The use, distribution or reproduction in other forums is permitted, provided the original author(s) or licensor are credited and that the original publication in this journal is cited, in accordance with accepted academic practice. No use, distribution or reproduction is permitted which does not comply with these terms.

Вступ. Запальні реакції що запускаються при застосуванні штучного кровообігу (ШК) підвищують проникність альвеоло капілярної мембрани 3 виходом в альвеолярний простір білків плазми та пошкодженням фосфоліпідного компонента комплексу сурфактанта [1-3]. Однак змінам піддається і протеїнових складова комплексу. Так, показано, що $\alpha$-фактор некрозу пухлин in vitro викликає зниження експресії генів САБ-А та САБ-В, це призводить до зниження концентрації даних білків сурфактанта протягом 6 - 12 год [4]. В кінці минулого століття були виконані роботи, що описують зміни комплексу сурфактанта при ШК на експериментальних моделях $[5,6]$. Проведені дослідження виявили збільшення проникності альвеолярного епітелію, підвищення кількості нейтрофілів та концентрації загального білка в бронхоальвеолярній промивній рідини.

У кількох інтраопераційних дослідженнях як джерело інформації про стан комплексу сурфактанта використовувалися трахеобронхіальні змиви $[7,8]$, що закономірно могло призводити до помилкових уявлень. Більш чутливим методом вивчення змін складу комплексу сурфактанта вважається біохімічне дослідження проб бронхоальвеолярної рідини [9]. $Є$ кілька вказівок на використання цього підходу при вивченні впливу ШК на комплекс сурфактанта. Так, було показано, що після кардіохірургічних утручаннях в пробах бронхоальвеолярної рідини вміст фосфоліпідів був меншим $[9,10]$. 
При дослідженні протеїнового компонента було продемонстровано зниження вмісту САБ-А та САБ-В в бронхоальвеолярних пробах, отриманих після припинення ШК [11]. Були продемонстрували дані, що свідчать про відносне зниження вмісту великих агрегатів сурфактанта та підвищенні кількості менш активних дрібних агрегатів після операцій на аорті [2]. Виконані в кінці минулого століття морфологічні дослідження виявили значні пошкодження клітинного компонента комплексу сурфактанта при операціях в умовах ШК. Так, при електронній мікроскопії біоптатів легень, отриманих при завершенні кардіохірургічних утручань, були виявлені істотні деструктивні зміни $[2,8]$. Зокрема, дослідники вказували на внутрішньоклітинний набряк, деформацію органел, зменшення відносного об'єму мітохондрій, руйнування цитолеми. Необхідно відзначити, що всі зазначені вище роботи були проведені на тлі неускладненого перебігу операцій на аорті. Нам не вдалося знайти досліджень, присвячених змінам у складі комплексу легеневого сурфактанта при гострому респіраторному дистрес синдрому (ГРДС) що розвинувся в післяопераційному періоді кардіохірургічних втручань.

Під час оперативних утручань на низхідному відділі грудної аорти виникає ряд факторів, що ведуть до пошкодження комплексу легеневого сурфактанта, яке відіграє визначальну роль в патогенезі післяопераційної гострої дихальної недостатності (ГДН) [12]. Несприятливі наслідки для якісного та кількісного складу комплексу сурфактанта має тривале колабування лівої легені, що супроводжується ішемією та подальшої реперфузією [1].

Проведені експериментальні та клінічні дослідження патогенезу реперфузійних ушкоджень легень, переконливо доведені [8]. Як в експериментальних [13], так і в клінічних дослідженнях [5] була виявлена можливість поліпшення показників газообміну та скорочення часу респіраторної підтримки при використанні препаратів сурфактанту у випадках ішемічного пошкодження легень.

Матеріали та методи. У пацієнтів оперованих з приводу гострого аортального синдрому було виконано 84 процедури бронхоальвеолярного лаважу (БАЛ) (42 перед початком операції та 42 в післяопераційному періоді). Біохімічному аналізу та цитологічному дослідженню були піддані 142 проби. У всіх випадках БАЛ проводили інтраопераційно або в ранньому післяопераційному періоді в умовах загальної анестезії та міорелаксації. Через просвіт ендотрахеальної трубки виконували бронхоскопію гнучким бронхоскопом. Використання спеціального адаптераобтуратора дозволяло продовжувати ШВЛ під час виконання бронхоскопії.

Отриману лаважну рідину піддавали центрифугуванню протягом 15 хв в режимі 1500 оборотів в хвилину. У всіх випадках проміжок часу 3 моменту виконання БАЛ до центрифугування не перевищував 20 хв. Надалі, відповідно до завдань, в над осадовій рідини визначали концентрацію загального білка, альбуміну, фібриногену, загальних фосфоліпідів та зміст продуктів деградації фібрину. Цитограми оцінювали на підставі підрахунку співвідношення у відсотках еозинофілів, нейтрофілів, лімфоцитів і макрофагів.

Результати. Дані про зміну біохімічного складу проб бронхоальвеолярної рідини, отримані до та після операцій, представлені в таблиці 1. Звертає на себе увагу достовірне збільшення вмісту загально білка та альбуміну в складі бронхоальвеолярної рідини, отриманої після кардіохірургічних операцій. Крім того, було виявлено достовірне збільшення співвідношення альбумін / загальний білок в післяопераційних пробах БАЛ. Ці факти свідчили про підвищення проникності альвеолярної мембрани, що могло бути як результатом реперфузійного пошкодженню при ШК, так і одним із проявів системної запальної відповіді. Підвищення інтраальвеолярного змісту плазмових білків вважається одним з провідних чинників пошкодженню комплексу сурфактанта. Особливо агресивно сурфактант інгібується фібриногеном.

Таблиця 1. Зміна біохімічного складу бронхоальвеолярної рідини при утручаннях 3 приводу гострого аортального синдрому $(\mathrm{M} \pm \sigma), \mathrm{n}=42$

\begin{tabular}{|c|c|c|}
\hline Показник & До операції & Після операції \\
\hline Загальний білок, мкг/мл & $826,5 \pm 122,9$ & $1006,2 \pm 168,3^{* *}$ \\
\hline Альбумін, мкг/мл & $187,5 \pm 80,4$ & $284 \pm 134,6^{* *}$ \\
\hline Альбумін/загальний білок, \% & $19,8 \pm 4,2$ & $24,6 \pm 5,2^{* *}$ \\
\hline Загальні фосфоліпіди, мкг/мл & $5,6 \pm 0,9$ & $5 \pm 2,5$ \\
\hline Фібриноген, мкг/мл & $1 \pm 0,2$ & $1,2 \pm 0,5$ \\
\hline$*$ - $\mathrm{p}<0,05 ; * *-p<0,01$. &
\end{tabular}


Виявлено тенденцію до збільшення вмісту фібриногену в бронхоальвеолярній рідині після операції, проте статистичної достовірності ця різниця не мала. Ймовірно, саме зі збільшенням вмісту плазмових білків в альвеолярному просторі була пов'язана тенденція до зниження загального вмісту фосфоліпідів в кінці операції, що проявлялося пошкодження комплексу сурфактанта.

Результати цитологічного дослідження бронхоальвеолярної рідини у хворих представлені в таблиці 2. Було виявлено достовірне збільшення вмісту нейтрофілів в пробах бронхоальвеолярної рідини в післяопераційному періоді. Вихід цих імунокомпетентних клітин в альвеолярне простір, на нашу думку, був пов'язаний 3 ініційованим ШК системною запальною відповіддю. Інших відмінностей в клітинному складі у до операційних та післяопераційних пробах знайдено не було.

Таблиця 2. Зміна клітинного складу бронхоальвеолярної рідини $(\mathrm{M} \pm \sigma), \mathrm{n}=42$

\begin{tabular}{|l|c|c|}
\hline \multicolumn{1}{|c|}{ Показник } & До операції & Після операції \\
\hline Макрофаги, \% від всіх клітин & $70,3 \pm 11,0$ & $69,3 \pm 7,2$ \\
\hline Нейтрофіли, \% від всіх клітин & $13,9 \pm 1,9$ & $16,2 \pm 4,9^{*}$ \\
\hline Еозинофіли, \% від всіх клітин & $0,14 \pm 0,08$ & $0,11 \pm 0,11$ \\
\hline Лімфоцити, \% від всіх клітин & $14,8 \pm 2,6$ & $16,6 \pm 4,4$ \\
\hline * - p <0,05
\end{tabular}

У трьох пацієнтів в післяопераційному періоді розвинулася гіпоксемія зі зниженням індексу $\mathrm{PaO}_{2} / \mathrm{FiO}_{2}$ менше 200 мм. рт. ст., що трактувалося як ГРДС та зажадало проведення продовженої респіраторної підтримки. Причиною розвитку пошкодження легень в двох спостереженнях була велика тривалість періодів штучного кровообігу (240 хв та 248 хв), в одному випадку - важка інтраопераційна крововтрата $(1850,0)$, яка вимагала трансфузії 4 доз еритроконцентрату та шести доз замороженої плазми.

Звертає на себе увагу те, що в цих випадках ми порівняли склад проб бронхоальвеолярної рідини, отриманих від початку до розвитку пошкодження легень, 3 пробами, набраними на фоні ГРДС. Результати біохімічного аналізу бронхоальвеолярної рідини цих хворих представлені у таблиці 3.

В післяопераційному періоді було виявлено достовірне збільшення вмісту альбуміну та фібриногену в бронхоальвеолярній рідини. Крім того, була знайдена тенденція до підвищення вмісту загального білка та співвідношення альбумін / загальний білок в післяопераційних пробах. Результатом пригнічуваної дії білків плазми стало пошкодження комплексу сурфактанта, що проявилося достовірним зниженням загального вмісту фосфоліпідів.

Таблиця 3. Зміна біохімічного складу бронхоальвеолярної рідини при утручаннях, що ускладнилися розвитком ГРДС, (медіана $(25 \% ; 75 \%$ - процентиль)) $(\mathrm{n}=3)$

\begin{tabular}{|c|c|c|}
\hline Показник & До операції & Після операції \\
\hline Загальний білок, мкг/мл & $770,8(679,2 ; 821,8)$ & $1208(1016,2 ; 1603,8)$ \\
\hline Альбумін, мкг/мл & $201,8(141 ; 204,1)$ & $482,9(463 ; 509,4)^{* *}$ \\
\hline Альбумін/загальний білок, \% & $26,2(17,2 ; 30)$ & $42,2(30,1 ; 45,6)$ \\
\hline Загальні фосфоліпіди, мкг/мл & $6,1(4,5 ; 6,1)$ & $2,8(1,4 ; 3,7)^{* *}$ \\
\hline Фібриноген, мкг/мл & $0,9(0,8 ; 1,1)$ & $2,3(1,5 ; 2,4)^{*}$ \\
\hline
\end{tabular}

$*$ - $\mathrm{p}<0,05 ; * *-\mathrm{p}<0,01$.

Використовуючи непараметричний метод (критерій Манна-Уїтні) ми провели порівняння біохімічного складу бронхоальвеолярної рідини пацієнтів без ознак післяопераційного ГРДС та хворих з ГРДС. При цьому не було знайдено достовірних відмінностей в до операційних пробах бронхоальвеолярної рідини.

У той же час, в післяопераційному періоді бронхоальвеолярна рідина хворих 3 порушеннями газообміну містила достовірно більше загального білка, альбуміну та фібриногену, що свідчило про підвищення проникності альвеолярної мембрани (таблиця 4). 
Таблиця 4. Порівняння біохімічного складу бронхоальвеолярної рідини, отриманої після операції у пацієнтів з розвиненим ГРДС та пацієнтів з відсутністю пошкоджень легень (медіана (25\%;75\% - процентиль)).

\begin{tabular}{|c|c|c|}
\hline Показник & Без ГРДС (39) & ГРДС (3) \\
\hline Загальний білок, мкг/мл & $979,8(925,3 ; 1048,7)$ & $1208(1016,2 ; 1603,8)^{*}$ \\
\hline Альбумін, мкг/мл & $270,9(209,8 ; 368,1)$ & $482,9(463 ; 509,4)^{* *}$ \\
\hline Альбумін/загальний білок, \% & $28,5(19,3 ; 34,8)$ & $42,2(30,1 ; 45,6)$ \\
\hline Загальні фосфоліпіди, мкг/мл & $4,2(3,5 ; 7)$ & $2,8(1,4 ; 3,7)^{*}$ \\
\hline Фібриноген, мкг/мл & $1,1(0,8 ; 1,4)$ & $2,3(1,5 ; 2,4)^{* *}$ \\
\hline
\end{tabular}

$*$ - $\mathrm{p}<0,05 ; * *-\mathrm{p}<0,01$.

Більш високий вміст білків плазми в альвеолярної рідині пацієнтів з ГРДС було причиною низького вмісту фосфоліпідів, що відображало пошкодження сурфактантної системи легень. Результати цитологічного аналізу бронхоальвеолярної рідини пацієнтів 3 післяопераційним ГРДС представлені в таблиці 5.

Таблиця 5. Зміна клітинного складу бронхоальвеолярної рідини при втручаннях, що ускладнилися розвитком ГРДС (медіана (25\%;75\% - процентиль)).

\begin{tabular}{|c|c|c|}
\hline Показник & До операції & Після операції \\
\hline Макрофаги, \% від всіх клітин & $74(70,4 ; 82,7)$ & $72,1(72,1 ; 76,7)$ \\
\hline Нейтрофіли, \% від всіх клітин & $15(15 ; 16,3)$ & $17,5(17,5 ; 22,6)$ \\
\hline Еозинофіли, \% від всіх клітин & $0,3(0,1 ; 0,3)$ & $0,2(0 ; 0,2)$ \\
\hline Лімфоцити, \% від всіх клітин & $16,7(15,9 ; 17,2)$ & $14,4(12,8 ; 15,8)$ \\
\hline
\end{tabular}

$*-\mathrm{p}<0,05$

Була виявлена тенденція до збільшення вмісту нейтрофілів в пробах бронхоальвеолярної рідини, виконаних після операції. Цю зміну відображало як зростання проникності альвеолярної мембрани, так і активація системної запальної відповіді.

Обговорення. При дослідженні виявлено достовірне збільшення вмісту загально білка та альбуміну в складі бронхоальвеолярної рідини, отриманої після кардіохірургічних операцій. Крім того, було виявлено достовірне збільшення співвідношення альбумін / загальний білок в післяопераційних пробах БАЛ. Ці факти свідчили про підвищення проникності альвеолярної мембрани, що могло бути як результатом реперфузійного пошкодженню при ШК, так і одним із проявів системної запальної відповіді. Підвищення інтраальвеолярного змісту плазмових білків вважається одним з провідних чинників пошкодженню комплексу сурфактанта. Особливо агресивно сурфактант інгібується фібриногеном. Необхідно відзначити, що в цих випадках ми порівняли склад проб бронхоальвеолярної рідини, отриманих від початку, до розвитку пошкодження легень, 3 пробами, набраними на тлі ГРДС. При порівнянні цитологічних показників БАЛ пацієнтів, які не мали ознак пошкодження легень в післяопераційному періоді, 3 клітинним складом бронхоальвеолярної рідини, отриманої при ГРДС, ми не знайшли статистично значущих відмінностей в до операційний та післяопераційних пробах.

Висновки. Після операцій 3 приводу гострого аортального синдрома в умовах штучного кровообігу в пробах бронхоальвеолярної рідини достовірно збільшується вміст загального білка та альбуміну, що свідчить про підвищення проникності альвеоло капілярної мембрани та може служити причиною пошкодження комплексу легеневого сурфактанту.

У пробах бронхоальвеолярної рідини, отриманих при гострому респіраторному дистрессиндромі після кардіохірургічних утручань, вміст загального білка, альбуміну та фібриногену вірогідно вище, а фосфоліпідів достовірно нижче, ніж у випадках неускладненого перебігу післяопераційного періоду.

Отримані дані вказують на ушкодження комплексу легеневого сурфактанта на тлі підвищення проникності альвеолярної мембрани при розвитку гострого респіраторного дистрес-синдрому після операцій на аорті. 


\section{REFERENCES}

1. Belov YV, Komarov RN, Stepanenko AB, Gasanov A.F. Legochno-plevral'nye oslozhnenija pri hirurgicheskom lechenii zabolevanij nishodjashhego otdela grudnoj aorty. Hirurgiya. Journal Pirogov N.I. 2013; 11: p. 16-19. [in Russian]

2. Wang J, Bian J, Wan X, Zhu KM, Sun ZZ, Lu AD Association between inflammatory genetic polymorphism and acute lung injury after cardiac surgery with cardiopulmonary bypass. Med Sci Monit. 2010; 16: 260 PMID:20424554; published May 2010

3. Guérin C Prone ventilation in acute respiratory distress syndrome. Eur Respir Rev. 2014; 23 : 249 - 257 PMID: 24881080, DOI:10.1183/09059180.00001114;

4. Taut FJ, Rippin G, Schenk P, Findlay G, Wurst W, Häfner D, et al. A Search for subgroups of patients with ARDS who may benefit from surfactant replacement therapy: a pooled analysis of five studies with recombinant surfactant protein-C surfactant (Venticute). Chest. 2008; 134: 724 - 732 PMID:18689599, DOI:10.1378/chest.08-0362;

5. Esteban A, Frutos-Vivar F, Muriel A. Evolution of mortality over time in patients receiving mechanical ventilation. Am J Respir Crit Care Med. 2013; 188: 220 - 230 PMID:23631814, DOI:10.1164/rccm.201212-21690C;

6. Guérin, C. Prone ventilation in acute respiratory distress syndrome. Eur Respir Rev. 2014; $23: 249$ - 257 PMID: 24881080, DOI:10.1183/09059180.00001114;

7. Vlaar AP, Cornet AD, Hofstra JJ, Porcelijn L, Beishuizen A, Kulik W, et al. The effect of blood transfusion on pulmonary permeability in cardiac surgery patients: a prospective multicenter cohort study. Transfusion. 2012; 52: 82 - 90 DOI: 10.1111/j.1537-2995.2011.03231.x;

8. Yeremenko AA, Levikov DI, Egorov VM Primenenie neinvazivnoj masochnoj vspomogatel'noj ventiljacii legkih pri ostrom respiratornom distress-sindrome $u$ kardiohirurgicheskih bol'nyh. Anesteziologiya $i$ reanimatologiya. 2004; №5: p.14 - 17 [in Russian]

9. Kogan A, Preisman S, Levin S, Raanani E, Sternik L Adult respiratory distress syndrome following cardiac surgery. J Card Surg. 2014; 29: 41 - 46 PMID:24299028, DOI:10.1111/jocs.12264; publishe $3^{\text {rd }}$ of December 2013

10. Fox A., Cooper J. Anesthetic management for thoracic aneurism and dissections. Cardiac anesthesia F. Hensley, D. Martin, G. Gravlee. 4th ed. - Philadelphia: Lippincott Williams and Wilkins. 2008. 653 - 694;

11. Aggarwal N., King L., D’Alessio F. Diverse macrophage populations mediate acute lung inflammation and resolution. Am. J. Physiol. Lung Cell. Mol. Physiol. 2014; 306: 709 - 725 PMID:24508730, PMCID:PMC3989724, DOI:10.1152/ajplung.00341.2013;

12. Cornet A.D., Kingma S.D., Trof R.J. Hepatosplanchnic ischemia/reperfusion is a major determinant of lung vascular injury after aortic surgery. J Surg Res. 2009; 157: 48 - 54 PMID:19482316, DOI:10.1016/j.jss.2008.09.021 